\title{
Characteristic Features of Reproductive Hormone Profiles in Late Adolescent and Adult Females with Complete Androgen Insensitivity Syndrome
}

\author{
Ulla Doehnert ${ }^{a}$ Silvano Bertelloni ${ }^{b}$ Ralf Werner ${ }^{a}$ Eleonora Dati ${ }^{c}$ Olaf Hiort ${ }^{a}$ \\ ${ }^{a}$ Division of Experimental Pediatric Endocrinology and Diabetes, Department of Pediatrics and Adolescent \\ Medicine, University of Lübeck, Lübeck, Germany; ${ }^{\mathrm{b}}$ Division of Pediatrics and ${ }^{\mathrm{C}}$ Division of Pediatric Oncology, \\ Department of Reproductive Medicine and Pediatrics, University of Pisa, Pisa, Italy
}

\section{Key Words}

Androgen receptor $\cdot$ Complete androgen insensitivity syndrome · Estrogens · Genetics · Gonadotropins .

Testosterone

\begin{abstract}
Little is known about gonadotropins and sex steroid levels in postpubertal women with complete androgen insensitivity syndrome (CAIS). In order to define reproductive hormone profiles in women with CAIS and intact gonads, 42 postpubertal females with proven CAIS (age range 14-50 years) with testes in situ were examined. Reproductive hormone values [testosterone (T), estradiol (E2), sex hormonebinding globulin (SHBG), luteinizing hormone (LH), folliclestimulating hormone (FSH)] were assessed by commercially available immunoassays. In women with CAIS, LH levels (median $18.5 \mathrm{IU} / \mathrm{I}$, range 5.5-51.1 IU/I) were elevated above the usual adult reference ranges, whereas $\mathrm{FSH}$ values (3.5 IU/I, 0.4-16.3 IU/I) were not. Basal T ( $20 \mathrm{nmol} / \mathrm{l}, 6-52 \mathrm{nmol} / \mathrm{l})$ and E2 values (113 pmol/l; 18-257 pmol/l) were found in the usual adult male reference ranges; SHBG levels (53 nmol/l, 15$180 \mathrm{nmol} / \mathrm{l}$ ) were in the adult female reference range. Calculated free androgen indices (Tx103/SHBG: 380, 114-863) and aromatization indices (E2/T: 0.052, 0.020-0.196) did not dif-
\end{abstract}

fer from the reference ranges for adult men given in the literature (Tx103/SHBG: 315-936; E2/T: 0.03-0.07). Reproductive hormone profiles in women with CAIS do not follow the usual male/female pattern, suggesting a specific postpubertal hormone milieu. Albeit calculation of CAIS-specific reference ranges requires larger series and standardization of laboratory methods, these results may be a prerequisite for the identification of pathologic hormone patterns in women with CAIS and gonads in situ. The present data will also be useful to monitor hormone replacement therapy in individuals with removed gonads.

(c) 2015 S. Karger AG, Basel

The complete androgen insensitivity syndrome (CAIS) represents one of the most common causes of 46,XY disorders of sex development (46,XY DSD) [Boehmer et al., 2001; Ahmed et al, 2010]. A mutation in the androgen receptor (AR) gene, mapping in region q11-12 on the $\mathrm{X}$ chromosome, is detected in more than $95 \%$ of women with CAIS. This results in a defective AR and a complete androgen resistance in androgen-dependent tissues. During intrauterine life, the lack of androgen effects involves regression of the Wolffian ducts and differentiation of the external female genitalia. At the same time, the effects of

\section{KARGER 125}

(c) 2015 S. Karger AG, Base

$1661-5425 / 15 / 0092-0069 \$ 39.50 / 0$

E-Mail karger@karger.com

www.karger.com/sxd
Olaf Hiort, MD, PhD, Division of Experimental Pediatric Endocrinology and Diabetes Department of Pediatrics and Adolescent Medicine University of Lübeck

Ratzeburger Allee 160, DE-23560 Lübeck (Germany)

E-Mail Olaf.Hiort@uksh.de 
the anti-Müllerian hormone produced in the testes by Sertoli cells usually result in a regression of Müllerian ducts and failure of development of fallopian tubes, uterus and the upper part of the vagina [Hughes et al., 2012].

Intrauterine androgen effects seem furthermore required for a transient postnatal activation of the hypothalamo-pituitary-gonadal axis in male infants, which was demonstrated by studies of postnatal changes of hormone profiles in infants with CAIS by Bouvattier et al. [2002]. In addition, early androgen effects seem to determine sexual dimorphism in $\mathrm{GnRH}$ pulse generator maturation, affecting the timing of the onset of puberty. Papadimitriou et al. [2006] followed 9 CAIS patients from birth to puberty and reported that they entered puberty closer to female than male standards. The pubertal activation of the hypothalamic-pituitary axis in females with CAIS induces testosterone synthesis in the testes [Hughes et al., 2012]. Nevertheless, pubarche is impaired by androgen resistance of target tissues, which leads to a phenotype with sparse or no pubic hair. Breast development is assumed to occur due to aromatization of testosterone to estradiol. Primary amenorrhea results from the absence of female internal genitalia [Hughes et al., 2012].

As a consequence of an increased risk of malignant degeneration of dysgenetic gonads or intra-abdominal testes, early gonadectomy has often been recommended in individuals with 46,XY DSD in the past decades. However, recent observations indicate that the risk of developing germ cell tumors before and during puberty is low in women with CAIS [Lecca et al., 1988; Cools et al., 2006; Hannema et al., 2006; Looijenga et al., 2007; Hersmus et al., 2008; Wünsch et al., 2012]. For those who underwent gonadectomy, hormone replacement therapy (HRT) is mandatory to induce puberty and improve bone health and well-being [Bertelloni et al., 2011].

Estrogens have usually been applied in the same dosage in CAIS as in female hypogonadism, where therapy aims at estradiol levels in the normal female reference range. However, outcome studies for DSD report little compliance with HRT in CAIS because of impaired wellbeing of the patients [Wisniewski et al., 2000; Warne, 2008]. Additionally, reduced bone mineral density has been reported in women with CAIS on HRT after gonadectomy [Sobel et al., 2006; Danilovic et al., 2007; Han et al., 2008; Bertelloni et al., 2010].

Data on gonadotropin values and sex hormones in postpubertal women with CAIS and intact gonads are rare. Available publications contain only small case series and several studies do not differentiate between complete and partial AIS. Existing studies report basal testosterone levels in the usual male reference range in adult women with CAIS and, therefore, increased compared with female reference ranges. FSH levels were also reported in the adult male reference range with elevated $\mathrm{LH}$ levels [MacDonald et al., 1979; Imperato-McGinley et al., 1985; Ahmed et al., 1999; Melo et al., 2003; Papadimitriou et al., 2006]. So far, an increased estrogen production both from the testes and as a result of peripheral aromatization has been assumed mainly referring to 2 publications from MacDonald et al. [1979] and Imperato-McGinley et al. [1985]. Melo et al. [2003] were the first to publish a series of 9 patients from different families with a CAIS phenotype, proven mutations in the AR gene and estradiol levels within the usual male reference range.

The objective of this study is to present characteristic features of reproductive hormone profiles of a large cohort of women with proven CAIS and to discuss implications for the management of androgen insensitivity and HRT after gonadal removal.

\section{Methods}

\section{Patients}

Clinical and laboratory data of 42 women with CAIS from 2 European centers for DSD in Lübeck, Germany, and Pisa, Italy, were analyzed. All women had a 46,XY karyotype and a CAIS phenotype with breast development, absent or sparse pubic hair and primary amenorrhea. They had completed breast development (stage B5) [Tanner and Whitehouse, 1976] and reached adult height with their gonads remaining in situ. Informed consent for scientific investigation was obtained from the patients or in case of minors from their guardians, and the study has been approved by the ethical committee of the participating institutions within the European Collaborative study 'EuroDSD'.

\section{Molecular Genetics}

The diagnosis of CAIS was confirmed by determining an inactivating mutation in the AR gene. DNA was extracted from blood leukocytes, and the individual exons of the AR gene were amplified specifically employing polymerase chain reaction before being subjected to direct sequencing on an ABI 3130 sequence analyzer. Mutation results are given according to the nomenclature described by Gottlieb et al. [2012] (www.androgendb.mcgill.ca).

\section{Hormone Analysis}

Laboratory data were obtained from all women with gonads in situ at the time of investigation. Hormone profiles included testosterone (T), estradiol (E2), sex hormone-binding globulin (SHBG), luteinizing hormone (LH) and follicle-stimulating hormone (FSH). Serum LH, FSH, T, E2, and SHBG were determined by commercially available electrochemilluminescence immunoassays on the Elecsys 2010-3 (Roche Diagnostics) in Lübeck. In Pisa, serum LH, FSH, T, E2, and SHBG were assessed by the VITROS ECi Immunodiagnostic System (Ortho Clinical Inc., Johnson \& Johnson). Results were compared to adult male and female refer- 


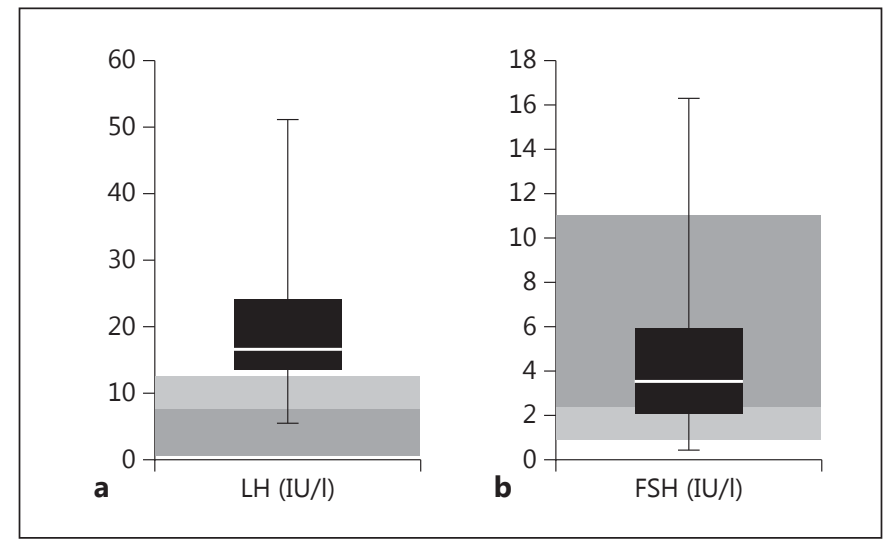

Fig. 1. $\mathrm{LH}$ and FSH values in CAIS depicted as box-and-whiskerplots.

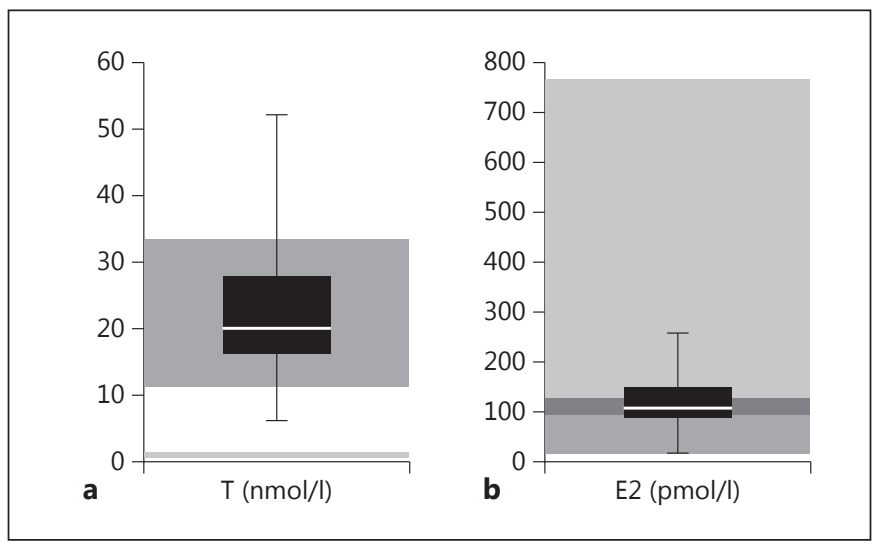

Fig. 2. T and E2 values in CAIS depicted as box-and-whisker-plots.

Table 1. Adult reproductive hormone reference ranges

\begin{tabular}{|c|c|c|c|c|c|c|c|c|c|c|}
\hline & \multicolumn{5}{|l|}{ Male } & \multicolumn{5}{|l|}{ Female } \\
\hline & $\mathrm{LH}^{\mathrm{a}}$ & $\mathrm{FSH}^{\mathrm{a}}$ & $\mathrm{T}^{\mathrm{b}}$ & $\mathrm{E} 2^{\mathrm{c}}$ & $\mathrm{SHBG}^{\mathrm{b}}$ & $\mathrm{LH}^{\mathrm{a}}$ & $\mathrm{FSH}^{\mathrm{a}}$ & $\mathrm{T}^{\mathrm{b}}$ & $\mathrm{E} 2^{\mathrm{c}}$ & $\mathrm{SHBG}^{\mathrm{b}}$ \\
\hline Lübeck & $0.4-7$ & $2.5-11$ & $12-34$ & $18-132$ & $23-55$ & $0.4-12$ & $1-11$ & $0.7-1.3$ & $99-774$ & $23-95$ \\
\hline Pisa & $1.4-12.7$ & $1.8-17$ & $9-38$ & $<74-184$ & $9-55$ & $2-10$ & $3-9$ & & $73-514$ & $20-85$ \\
\hline Brook et al. [2009] & $1-10$ & $1-7$ & $10-30$ & $<150$ & & $2-6.6$ & $2-6.6$ & $0.5-2.5$ & $70-260$ & \\
\hline
\end{tabular}

Female values correspond to the early follicular phase. ${ }^{a} \mathrm{IU} / \mathrm{l} .{ }^{\mathrm{b}} \mathrm{nmol} / \mathrm{l} .{ }^{\mathrm{c}} \mathrm{pmol} / \mathrm{l}$.

ence ranges applied in the 2 laboratories in Lübeck and Pisa (table 1). These match the reference ranges given by Brook et al. [2009].

From the results of the laboratory analysis, the $\mathrm{T} \times \mathrm{LH}$ product was calculated as an index of androgen sensitivity and compared with reference ranges of 55 fertile Caucasian men provided by Hiort et al. [2000]. The free androgen index was calculated by multiplying values for T by 1000/SHBG. Reference ranges for the T/ SHBG ratio were established by Sinnecker [1993]. Aromatization of testosterone to estradiol was assessed by the estradiol-to-testosterone (E2/T) ratio, for which de Ronde et al. [2005] published data from 399 eugonadal men from the age of 40 to 80 years. All hormone data were reported as median and range.

\section{Results}

At the time of hormone analysis, the age of the women with CAIS ranged from 14 to 50 years (median 17.3 years), with 5 women older than 30 years. The mutations found in the 42 women are shown in table 2 . In the same table, the individual hormone data are presented. T was measured in all women. Gonadotropins were not available from one person; E2 was not measured in 4, SHBG in 11 individuals.

Serum LH levels ranged from 5.5 to $51.1 \mathrm{IU} / \mathrm{l}$ and were increased in comparison to both male and female reference ranges with a median of $18.5 \mathrm{IU} / \mathrm{l}$ (fig. 1a). Six women had normal LH levels with respect to local reference ranges (table 2). Serum FSH levels were measured in the male reference range with a median of $3.5 \mathrm{IU} / \mathrm{l}$ and a range from 0.4 to $16.3 \mathrm{IU} / 1$ (fig. 1b). Two women (Nos. 3 and 24) showed FSH values elevated above the local reference range with typical T levels (table 2). Inhibin B as an additional marker of Sertoli cell function was not determined in both women. One woman developed a focal testicular intraepithelial neoplasia; the other did not show any histological abnormalities on a biopsy during gonadopexy.

The median T (20 nmol/l; range 6-52 nmol/l) matches the male reference range (fig. 2a). Five women (Nos. 6, 8, 30,36 , and 40) showed T levels below this, but still markedly elevated above the female reference ranges (table 2). E2 levels ranged from 18 to $257 \mathrm{pmol} / 1$ (median of 113 pmol/l) (fig. 2b). Nine women had increased E2 levels 
Table 2. Hormone data and AR gene mutations

\begin{tabular}{|c|c|c|c|c|c|c|c|c|c|c|c|}
\hline \multirow[t]{2}{*}{ No. } & \multirow{2}{*}{$\begin{array}{l}\text { Age, } \\
\text { years }\end{array}$} & \multirow{2}{*}{$\begin{array}{l}\mathrm{LH}, \\
\mathrm{IU} / \mathrm{l}\end{array}$} & \multirow{2}{*}{$\begin{array}{l}\text { FSH, } \\
\text { IU/l }\end{array}$} & \multirow{2}{*}{$\begin{array}{l}\mathrm{T}, \\
\mathrm{nmol} / \mathrm{l}\end{array}$} & \multirow{2}{*}{$\begin{array}{l}\mathrm{E} 2, \\
\mathrm{pmol} / \mathrm{l}\end{array}$} & \multirow{2}{*}{$\begin{array}{l}\text { SHBG, } \\
\mathrm{nmol} / \mathrm{l}\end{array}$} & \multirow{2}{*}{$\begin{array}{l}\text { ASI, } \\
\text { LHxT }\end{array}$} & \multirow{2}{*}{$\begin{array}{l}\mathrm{AI} \\
\mathrm{E} 2 / \mathrm{T}\end{array}$} & \multirow{2}{*}{$\begin{array}{l}\text { FAI, } \\
\mathrm{Tx} 10^{3} / \mathrm{SHBG}\end{array}$} & \multicolumn{2}{|l|}{ AR mutation } \\
\hline & & & & & & & & & & gene & protein \\
\hline 1 & 14 & 22.9 & 1.0 & 16.1 & 224 & 51 & 368.7 & 0.131 & 313 & c.2301del & p. $\left(\right.$ Asp768Ilefs $\left.{ }^{\star} 21\right)$ \\
\hline 2 & 14.4 & 5.5 & 2.0 & 24.3 & 73 & 88 & 133.5 & 0.029 & 275 & c. $2194 \mathrm{G}>\mathrm{T}$ & p.(Asp732Tyr) \\
\hline 3 & 14.6 & 15.3 & 16.3 & 22.9 & 113 & 41 & 350.1 & 0.049 & 552 & c. $2248 \mathrm{~A}>\mathrm{G}$ & p.(Met750Val) \\
\hline 4 & 15 & 6.8 & 3.4 & 52.1 & 126 & - & 353.8 & 0.023 & - & c. $2599 \mathrm{G}>\mathrm{A}$ & p.(Val867Met) \\
\hline 5 & 15 & 12.2 & 2.5 & 10.3 & 125 & 21 & 125.7 & 0.114 & 500 & c. $2173 \mathrm{G}>\mathrm{A}$ & p.(Gly725Ser) \\
\hline 6 & 15 & 21.0 & 15.7 & 6.9 & 143 & - & 144.9 & 0.196 & - & del exons $1-8$ & \\
\hline 7 & 15.8 & 51.1 & 5.1 & 26.0 & 125 & 61 & 1328.6 & 0.045 & 424 & c. $2603 \mathrm{~A}>\mathrm{G}$ & p. (Gln868Arg) \\
\hline 8 & 16 & - & - & 8.7 & 88 & 35 & - & 0.096 & 248 & c. $1847 \mathrm{G}>\mathrm{A}$ & p.(Arg616His) \\
\hline 9 & 16 & 17.4 & 7.1 & 29.1 & 62 & 42 & 506.7 & 0.02 & 695 & c. $232 \mathrm{C}>\mathrm{T}$ & p. $\left(\mathrm{G} \ln 78^{\star}\right)$ \\
\hline 10 & 16.4 & 16.7 & 1.8 & 15.6 & 95 & - & 260.5 & 0.058 & - & c. $1426 \mathrm{G}>\mathrm{T}$ & p. $\left(\right.$ Gly $\left.476^{*}\right)$ \\
\hline 11 & 16.4 & 40.6 & 4.3 & 12.3 & 172 & - & 497.8 & 0.141 & - & c. $2296 \mathrm{G}>\mathrm{A}$ & p.(Ala766Thr) \\
\hline 12 & 16.6 & 16.2 & 1.8 & 21.8 & 103 & 49 & 353.1 & 0.047 & 443 & c. $1696 \mathrm{G}>\mathrm{T}$ & p.(Glu566*) \\
\hline 13 & 16.8 & 21.0 & 1.9 & 17.0 & 95 & - & 356.4 & 0.053 & - & c. $2113 \mathrm{C}>\mathrm{T}$ & p.(Leu705Phe) \\
\hline 14 & 17 & 18.3 & 3.0 & 19.3 & - & 64 & 353.7 & - & 302 & c. $1736 \mathrm{G}>\mathrm{T}$ & p.(Ser579Ile) \\
\hline 15 & 17 & 44.1 & 8.7 & 13.5 & - & - & 593.6 & - & - & c.428_453del & p.(Lys143Thrfs ${ }^{*}$ ) \\
\hline 16 & 17 & 11.4 & 3.1 & 28.5 & - & - & 325.1 & - & - & c. $2678 \mathrm{C}>\mathrm{T}$ & p.(Pro893Leu) \\
\hline 17 & 17 & 19.5 & 3.0 & 28.4 & 86 & - & 553.8 & 0.028 & - & c. $2391 \mathrm{G}>\mathrm{A}$ & p. $\left(\operatorname{Trp} 797^{\star}\right)$ \\
\hline 18 & 17 & 22.0 & 2.1 & 22.5 & 209 & - & 495.9 & 0.088 & - & c. $1616+4 \mathrm{del} A$ & splice site mut \\
\hline 19 & 17 & 25.4 & 1.7 & 24.5 & 103 & 33 & 622.3 & 0.04 & 749 & c. $2173 \mathrm{G}>\mathrm{A}$ & p.(Gly725Ser) \\
\hline 20 & 17.1 & 22.6 & 8.9 & 16.3 & 88 & 38 & 367.7 & 0.051 & 426 & c. $2111 \mathrm{G}>\mathrm{T}$ & p.(Ser704Ile) \\
\hline 21 & 17.3 & 17.0 & 6.0 & 19.3 & 185 & 52 & 327.5 & 0.09 & 372 & c. $2324 \mathrm{G}>\mathrm{A}$ & p.(Arg775His) \\
\hline 22 & 17.3 & 14.9 & 4.3 & 46.2 & 100 & 54 & 687.6 & 0.02 & 863 & c. $2599 \mathrm{G}>\mathrm{A}$ & p.(Val867Met) \\
\hline 23 & 17.3 & 24.5 & 6.8 & 20.1 & 78 & 62 & 493.4 & 0,037 & 326 & c. $1715 A>G$ & p.(Tyr572Cys) \\
\hline 24 & 17.7 & 21.4 & 11.1 & 21.2 & 118 & 60 & 453.2 & 0.052 & 351 & c. $2722 \mathrm{C}>\mathrm{T}$ & p.(Leu908Phe) \\
\hline 25 & 17.7 & 18.7 & 7.1 & 29.4 & 153 & 37 & 549.8 & 0.052 & 800 & c. $2248 \mathrm{~A}>\mathrm{G}$ & p.(Met750Val) \\
\hline 26 & 18.3 & 26.0 & 5.3 & 38.2 & 169 & 70 & 992.4 & 0.042 & 545 & c. $2384 \mathrm{~T}>\mathrm{C}$ & p.(Phe795Ser) \\
\hline 27 & 18.3 & 13.0 & 3.7 & 14.8 & 63 & 99 & 192.7 & 0.04 & 150 & c.648_649insC & p. (Ala217Argfs $\left.{ }^{\star} 18\right)$ \\
\hline 28 & 18.3 & 23.8 & 2.4 & 34.5 & 211 & 77 & 820.1 & 0.058 & 447 & c. $1847 \mathrm{G}>\mathrm{A}$ & p.(Arg616His) \\
\hline 29 & 19.4 & 31.7 & 5.9 & 20.1 & 129 & 79 & 635.5 & 0.061 & 253 & c.2453del & p. $\left(\right.$ Pro818Glnfs $\left.{ }^{*} 5\right)$ \\
\hline 30 & 19.8 & 21.3 & 2.2 & 7.1 & 60 & 63 & 151.9 & 0.079 & 114 & c. $1721 \mathrm{C}>\mathrm{A}$ & p.(Ala574Asp) \\
\hline 31 & 20.1 & 30.0 & - & 28.6 & - & 96 & 857.7 & - & 298 & c. $2317 \mathrm{G}>\mathrm{T}$ & p. $($ Glu773*) \\
\hline 32 & 20.2 & 16.0 & 3.1 & 19.1 & 121 & 29 & 305 & 0.06 & 659 & c. $1605 \mathrm{C}>\mathrm{A}$ & p. $\left(\right.$ Tyr $\left.535^{\star}\right)$ \\
\hline 33 & 20.6 & 24.7 & 5.8 & 16.1 & 84 & 60 & 396.1 & 0.05 & 270 & c.549_550del & p.(Ile184Profs ${ }^{\star} 50$ ) \\
\hline 34 & 21.2 & 11.4 & 1.0 & 32.1 & 123 & 89 & 365.6 & 0.038 & 362 & c. $1696 \mathrm{G}>\mathrm{T}$ & p. $($ Glu566 $)$ \\
\hline 35 & 21.8 & 27.0 & 3.8 & 30.5 & 162 & - & 824.6 & 0.05 & - & c. $2318+1 \mathrm{G}>\mathrm{A}$ & splice site mut \\
\hline 36 & 23.2 & 17.7 & 3.5 & 8.6 & 50 & 69 & 152.3 & 0.055 & 124 & c. $1721 \mathrm{C}>\mathrm{A}$ & p.(Ala574Asp) \\
\hline 37 & 25 & 8.0 & 2.4 & 17.0 & 257 & 38 & 135.9 & 0.143 & 450 & c. $1617-2 \mathrm{~A}>\mathrm{C}$ & splice site mut \\
\hline 38 & 31 & 11.4 & 0.7 & 19.4 & 103 & 52 & 221.4 & 0.05 & 376 & c. $259 \mathrm{C}>\mathrm{T}$ & p. $\left(\mathrm{G} \ln 87^{\star}\right)$ \\
\hline 39 & 36 & 10.1 & 1.9 & 9.7 & 114 & 16 & 98.1 & 0.111 & 603 & c.1564_1567delinsTGCT & p.(Ser522_Gln920delinsCys) \\
\hline 40 & 36 & 9.1 & 0.4 & 6.2 & 95 & 15 & 56.8 & 0.144 & 426 & c.1564_1567delinsTGCT & p.(Ser522_Gln920delinsCys) \\
\hline 41 & 40 & 13.4 & 4.0 & 19.5 & 18 & 51 & 260.9 & 0.009 & 380 & c. $2296 \mathrm{G}>\mathrm{A}$ & p.(Ala766Thr) \\
\hline 42 & 50 & 13.6 & 5.4 & 20.8 & 217 & - & 282.5 & 0.104 & - & c. $1196 \mathrm{G}>\mathrm{A}$ & p. $\left(\operatorname{Trp} 399^{*}\right)$ \\
\hline
\end{tabular}

ASI = Androgen sensitivity index; $\mathrm{AI}=$ androgen insensitivity; $\mathrm{FAI}=$ free androgen index.

compared with local male reference ranges and in the low female reference ranges. In 2 individuals (Nos. 2, 9), E2 levels were decreased below adult male reference ranges in the presence of T values in the usual male reference interval (table 2). In one of these cases, E2 was below the detection limit of the assay and, therefore, was not included in statistical analyses. The median SHBG (53 $\mathrm{nmol} / \mathrm{l}$; range 15-99 $\mathrm{nmol} / \mathrm{l}$ ) equates to the adult female reference range. SHBG levels were decreased below the local female reference range in 2 women (Nos. 39, 40) (table 2).
Calculation of the free androgen index resulted in a median of 380 (range 114-863). The calculated free androgen indices correspond with the male reference ranges (315-936) given by Sinnecker [1993]. The E2/T ratio ranged from 0.01 to 0.20 with a median of 0.052 . De Ronde et al. [2005] gave a reference range from 0.03 to 0.07 for $40-80$-year-old men. The $\mathrm{LH} \times \mathrm{T}$ product was increased with respect to the values found in adult males (6.7-138.7 IU $\times \mathrm{nmol} \times \mathrm{l}^{-2}$ ) [de Ronde et al., 2005]. Five individuals had an androgen sensitivity index (Nos. 2, 5, 37,39 , and 40 ) within the male reference range. 


\section{Discussion}

In this study, the reproductive hormone profiles of a large cohort of postpubertal women with CAIS and intact gonads are reported, providing relevant information about physiological hormone levels in this form of 46,XY DSD.

Our population was very heterogenous with regard to age and the underlying mutation in the AR gene, while all subjects had reached final height and breast stage B5, suggesting the achievement of full sexual maturity. However, flawless standardized instruments to evaluate pubertal progression in this rare condition are not available so far. All probands had postpubertal hormone levels regardless of age, and all hormone levels varied independent of underlying missense or nonsense mutations (table 2). Therefore, we did not interpret hormone profiles according to pubertal stage, age or mutation type.

The increase in LH levels in spite of high serum T levels confirms the role of the AR in the negative feedback of androgens on the pituitary [Papadimitriou et al., 2006; Hughes et al., 2012]. Expression of the AR in the anterior pituitary has been proven in animal models [Huang and Yuan, 2011]. In contrast, secretion of FSH is predominantly regulated by inhibins produced in testicular cells [Hayes et al., 2001]; therefore, serum levels of this gonadotropin are not influenced by androgen insensitivity. In accordance, serum FSH levels in our sample of women with CAIS do not differ from other adults with intact gonads.

Little attention had been paid to E2 levels in women with CAIS. Existing studies are limited by small case numbers, possible interactions with other hormone abnormalities due to intermarriage within one pedigree and unavailable proof of underlying mutations in the AR gene [MacDonald et al., 1979; Imperato-McGinley et al., 1985]. In our population, median E2 levels were measured in the usual male reference range, in agreement with the findings of Melo et al. [2003]. There was no correlation between $\mathrm{T}$ and $\mathrm{E} 2$ values, suggesting that the serum levels of the 2 hormones are not interrelated at least in this type of 46,XY DSD. Nine women had elevated E2 levels, showing a high aromatization index at the same time. Our mean E2/T-ratio was within the upper range of 40-80-year-old men described by de Ronde et al. [2005] with a higher range, which did not result in increased serum E2 levels as assumed in the past. Therefore, breast development in women with CAIS could result from unopposed estrogen effects in the presence of androgen resistance as postulated by Melo et al. [2003], increased susceptibility in target tissues or androgen insensitivity itself.

Serum $\mathrm{T}$ levels were in the usual male reference range with no apparent androgen effects due to androgen resistance in target tissues including the pituitary gland. At the same time, there is no increase in free testosterone.

Our data reveal characteristic reproductive hormone profiles that should result in CAIS-specific reference intervals and do not follow the usual male/female pattern. However, implementation of such reference ranges is statistically limited by small case numbers and standardization of hormone assessment in the participating centers. Since other analytes such as dihydrotestosterone, which has been reported to be decreased in women with CAIS [Imperato-McGinley et al., 1985; Melo et al., 2003], may follow distinct CAIS ranges, a larger panel of analytes should be included in further studies and should be uniformly determined best with LC-MS/MS methodology. In addition, age-related and pubertal stage-related values should be investigated in larger populations, if available. Furthermore, hitherto unknown parameters might influence hormone values and profiles in CAIS as they also do in usual reference populations resulting in broad reference ranges.

As the development of malignancy before and during puberty is probably lower in CAIS than previously estimated and gonadectomy is to be performed on an individual decision process, the knowledge of CAIS-specific hormone profiles will be a prerequisite for the interpretation of possible pathologic patterns and consequent therapeutic options. Our findings would also imply a different approach to HRT in those women with CAIS who underwent gonadectomy. E2 replacement therapy currently aims at much higher estradiol levels in the female reference range, whereas $T$ substitution is not a common practice [Bertelloni et al., 2011]. Malcompliance with HRT due to impaired physical well-being may be related to unphysiological hormone profiles with such therapy. Further studies are needed to evaluate HRT, considering the characteristic reproductive hormone profiles of CAIS.

\section{Acknowledgements}

The authors are indebted to Dr. F. Baldinotti (Laboratory of Medical Genetics, Pisa University Hospital) for AR gene analysis in the Italian sample. 


\section{References}

Ahmed SF, Cheng A, Hughes IA: Assessment of the gonadotropin-gonadal axis in androgen insensitivity syndrome. Arch Dis Child 80: 324-329 (1999).

Ahmed SF, Rodie M, Jiang J, Sinnott RO: The European disorder of sex development registry: a virtual research environment. Sex Dev 4: 192-188 (2010).

Bertelloni S, Baroncelli GI, Mora S: Bone health in disorders of sex differentiation. Sex Dev 4: 270-284 (2010).

Bertelloni S, Dati E, Baroncelli GI, Hiort O: Hormonal management of complete androgen insensitivity syndrome from adolescence onward. Horm Res Paediatr 76:428-433 (2011).

Boehmer AL, Brinkmann O, Brüggenwirth $\mathrm{H}$, van Assendelft C, Otten BJ, et al: Genotype versus phenotype in families with androgen insensitivity syndrome. J Clin Endocrinol Metab 86:4151-4160 (2001).

Bouvattier C, Carel JC, Lecointre C, David A, Sultan $\mathrm{C}$, et al: Postnatal changes of T, LH, and $\mathrm{FSH}$ in 46,XY infants with mutations in the AR gene. J Clin Endocrinol Metab 87:29-32 (2002).

Brook CGD, Clayton P, Brown R: Brook's Clinical Pediatric Endocrinology (John Wiley \& Sons, New York 2009).

Cools M, Drop SL, Wolffenbuttel KP, Oosterhuis JW, Looijenga LH: Germ cell tumors in the intersex gonad: old paths, new directions, moving frontiers. Endocr Rev 27:468-484 (2006).

Danilovic DL, Correa PH, Costa EM, Melo KF, Mendonca BB, Arnhold IJ: Height and bone mineral density in androgen insensitivity syndrome with mutations in the androgen receptor gene. Osteoporos Int 18:369-374 (2007).

de Ronde W, van der Schouw YT, Muller M, Grobbee DE, Gooren LJ, et al: Associations of sex-hormone-binding globulin (SHBG) with non-SHBG-bound levels of testosterone and estradiol in independently living men. J Clin Endocrinol Metab 90:157-162 (2005).

Gottlieb B, Beitel LK, Nadarajah A, Paliouras M, Trifiro M: The androgen receptor gene mutations database: 2012 update. Hum Mutat 33: 887-894 (2012).
Han TS, Goswami D, Trikudanathan S, Creighton SM, Conway GS: Comparison of bone mineral density and body proportions between women with complete androgen insensitivity syndrome and women with gonadal dysgenesis. Eur J Endocrinol 159:179-185 (2008).

Hannema SE, Scott IS, Rajpert-De Meyts E, Skakkebaek NE, Coleman N, Hughes IA: Testicular development in the complete androgen insensitivity syndrome. J Pathol 208:518-527 (2006).

Hayes FJ, Pitteloud N, DeCruz S, Crowley WF Jr, Boepple PA: Importance of inhibin B in the regulation of $\mathrm{FSH}$ secretion in the human male. J Clin Endocrinol Metab 86:5541-5546 (2001).

Hersmus R, de Leeuw BH, Wolffenbuttel KP, Drop SL, Oosterhuis JW, et al: New insights into type II germ cell tumor pathogenesis based on studies of patients with various forms of disorders of sex development (DSD). Mol Cell Endocrinol 291:1-10 (2008).

Hiort O, Holterhus PM, Horter T, Schulze W, Kremke B, et al: Significance of mutations in the androgen receptor gene in males with idiopathic infertility. J Clin Endocrinol Metab 85:2810-2815 (2000).

Huang LB, Yuan XJ: Expression of androgen receptor and estrogen receptor-alpha in the developing pituitary gland of male sheep lamb. Anim Reprod Sci 127:164-168 (2011).

Hughes IA, Werner R, Bunch T, Hiort O: Androgen insensitivity syndrome. Semin Reprod Med 30:432-442 (2012).

Imperato-McGinley J, Binienda Z, Arthur A, Mininberg DT, Vaughan ED Jr, Quimby FW: The development of a male pseudohermaphroditic rat using an inhibitor of the enzyme 5 alpha-reductase. Endocrinology 116:807-812 (1985).

Lecca U, Parodo G, Fiore R, Martino E: Embryonal carcinoma in two cases of androgen insensitivity syndrome: clinical, endocrinological and pathological features. Eur J Gynaecol Oncol 9:489-496 (1988).

Looijenga LH, Hersmus R, Oosterhuis JW, Cools M, Drop SL, Wolffenbuttel KP: Tumor risk in disorders of sex development (DSD). Best Pract Res Clin Endocrinol Metab 21:480-495 (2007).
MacDonald PC, Madden JD, Brenner PF, Wilson JD, Siiteri PK: Origin of estrogen in normal men and in women with testicular feminization. J Clin Endocrinol Metab 49:905-916 (1979).

Melo KF, Mendonca BB, Billerbeck AE, Costa $\mathrm{EM}$, Inácio $\mathrm{M}$, et al: Clinical, hormonal, behavioral, and genetic characteristics of androgen insensitivity syndrome in a Brazilian cohort: five novel mutations in the androgen receptor gene. J Clin Endocrinol Metab 88: 3241-3250 (2003).

Papadimitriou DT, Linglart A, Morel Y, Chaussain JL: Puberty in subjects with complete androgen insensitivity syndrome. Horm Res 65: 126-131 (2006).

Sinnecker H: Sexualhormon bindendes globulin: Physiologische Bedeutung im Wirkungsmechanismus der Steroidhormone und klinische Bedeutung für die Diagnostik endokriner Erkrankungen [in German]. (Georg Thieme Verlag, Stuttgart 1993).

Sobel V, Schwartz B, Zhu YS, Cordero JJ, Imperato-McGinley J: Bone mineral density in the complete androgen insensitivity and 5alphareductase-2 deficiency syndromes. J Clin Endocrinol Metab 91:3017-3023 (2006).

Tanner JM, Whitehouse RH: Clinical longitudinal standards for height, weight, height velocity, weight velocity, and stages of puberty. Arch Dis Child 51:170-179 (1976).

Warne GL: Long-term outcome of disorders of sex development. Sex Dev 2:268-277 (2008).

Wisniewski AB, Migeon CJ, Meyer-Bahlburg HF, Gearhart JP, Berkovitz GD, et al: Complete androgen insensitivity syndrome: long-term medical, surgical, and psychosexual outcome. J Clin Endocrinol Metab 85:2664-2669 (2000).

Wünsch L, Holterhus PM, Wessel L, Hiort O: Patients with disorders of sex development (DSD) at risk of gonadal tumour development: management based on laparoscopic biopsy and molecular diagnosis. BJU Int 110:E958-965 (2012). 


\section{Erratum}

In the article by Doehnert et al., entitled 'Characteristic features of reproductive hormone profiles in late adolescent and adult females with complete androgen insensitivity syndrome' [2015;9:69-74], in the reference list unfortunately a wrong article is cited referring to estrogen levels in complete androgen insensitivity syndrome. Instead of ImperatoMcGinley et al. [1985], it should be Imperato-McGinley J, Peterson RE, Gautier T, Cooper G, Danner R, Arthur A, Morris PL, Sweeney WJ, Shackleton C: Hormonal evaluation of a large kindred with complete androgen insensitivity: evidence for secondary $5 a$-reductase deficiency. J Clin Endocrinol Metab 1982;54:931-941. 